\title{
Faktor-Faktor Yang Berhubungan dengan Penyembuhan Luka Post SC Pada Ibu nifas Di RSUD Hj.Anna Lasmanah Banjarnegara
}

\author{
Dian Nirmala Sari ${ }^{1}$, Umi Nur Fajri ${ }^{2}$ \\ Prodi DIII Kebidanan Politeknik Banjarnegara, Jawa Tengah, Indonesia \\ Email corresponding: nirmalasaridian026@gmail.com
}

\begin{abstract}
ABSTRAK
Sectio Cesarea (SC) merupakan metode operasi modern diabad 20 yang berperan dalam menurunkan morbidity rate dan mortality rate pada ibu bersalin. Pada persalinan dengan tindakan SC meningkatkan angka mortalitas dua kali dari angka persalinan pervaginam, angka morbiditas juga lebih tinggi pada persalinan SC. 90\% dari morbiditas pasca operasi disebabkan oleh infeksi (infeksi pada rahim atau endometritis, alat- alat berkemih, dan luka operasi. Penelitian ini dilakukan untuk mengetahui faktor- faktor yang berhubungan dengan penyembuhan luka post SC pada ibu nifas. Desain studi analitik dengan pendekatan cross sectional, dengan menggunakan data sekunder. Variebel penelitian indikasi SC, anemia, riwayat DM, penyembuhan luka. Indikasi SC, anemia dengan penyembuhan luka post SC nilai $p$ value lebih dari 0,005 yang berarti tidak ada hubungan antara indikasi SC, anemia terhadap penyembuhan luka. Sedangkan untuk variabel riwayat DM dengan penyembuhan luka post SC $p$ value kurang 0,005 yang berarti ada hubungan terhadap penyembuhan luka.
\end{abstract}

Kata Kunci:Anemia, Indikasi SC, Riwayat DM, Penyembuhan Luka.

Cesarean Sectio (SC) is a modern method of operation in the 20th century that plays a role in reducing the morbidity and mortality rates of mothers. In labor with CS measures, the mortality rate is twice that of vaginal delivery, morbidity is also higher in SC labor. $90 \%$ of postoperative morbidity is caused by infection (infection of the uterus or endometritis, urinary instruments, and surgical wounds. This study was conducted to determine factors associated with post SC wound healing in postpartum mothers. Design analytic study with cross approach sectional, using secondary data.The research variables were indicative of SC, anemia, history of DM, wound healing Indication of SC, anemia with post SC wound healing value of $\mathrm{p}$ value was more than 0.005 which means there was no relationship between SC indication, anemia on wound healing. for DM history variable with post SC wound healing $\mathrm{p}$ value less 0.005 which means there is a relationship to wound healing.

Keywords: Anemia, SC indications, DM history, wound healing.

\section{PENDAHULUAN}

Sectio Cesarea (SC) merupakan metode operasi modern di bidang teknologi kedokteran khususnya dalam metode persalinan yang membawa manfaat besar bagi keselamatan ibu dan bayi serta mempermudah proses persalinan ${ }^{1}$. Di Indonesia persalinan dengan SC sudah melewati batas maksimal standar WHO yaitu 5-15 $\%^{2}$. Pada persalinan dengan tindakan SC akan meningkatkan angka mortalitas yaitu dua kali dari angka persalinan pervaginam, angka morbiditas juga lebih tinggi pada persalinan $S C$ hal ini diakibatkan karena adanya infeksi salah satunya karena luka post $\mathrm{SC}{ }^{3}$. Faktor umum yang mempengaruhi penyembuhan luka yaitu penyakit ibu seperti anemia, diabetes dan obat-obatan, serta indikasi persalinan $\mathrm{SC}^{4}$.

\section{METODE PENELITIAN}

Teknik sampling dalam penelitian ini adalah non probability sampling jenis consecutive sampling, yaitu semua subjek memenuhi kriteria dimasukkan dalam penelitian sampai jumlah subjek yang diperlukan terpenuhi. Penelitian ini dilakukan di RSUD Hj. Anna Lasmanah Banjarnegara menggunakan desain studi analitik dengan metode cross sectional, pada bulan mei- juni 2019. Subjek penelitian adalah nifas post SC di RSUD Hj.Anna Lasmanah Banjarnegara.

\section{HASIL PENELITIAN}

Karakteristik dalam penelitian ini terdiri dari indikasi SC, anemia, riwayat DM 
Tabel 1. Karakteristik responden

\begin{tabular}{|c|c|c|c|c|c|c|}
\hline \multirow{3}{*}{ Variabel } & \multicolumn{4}{|c|}{ Penyembuhan Luka } & \multirow{2}{*}{\multicolumn{2}{|c|}{ Total }} \\
\hline & \multicolumn{2}{|c|}{ Baik } & \multicolumn{2}{|c|}{ Tidak baik } & & \\
\hline & $\mathrm{N}$ & $\%$ & $\mathrm{~N}$ & $\%$ & $\mathrm{~N}$ & $\%$ \\
\hline \multicolumn{7}{|l|}{ Indikasi SC } \\
\hline Resiko infeksi & 4 & 57,1 & 3 & 42,9 & 7 & 18,4 \\
\hline Tidak resike infeksi & 19 & 79,2 & 5 & 20,8 & 24 & 63.3 \\
\hline Riwayat SC & 4 & 51,7 & 3 & 42,9 & 7 & 18,4 \\
\hline \multicolumn{7}{|l|}{ Anemia } \\
\hline Anemia & 2 & 25,9 & 0 & 0 & 15 & 39,5 \\
\hline Tidak anemia & 20 & 74,1 & 11 & 47,8 & 23 & 60,5 \\
\hline \multicolumn{7}{|l|}{ Riwayat DM } \\
\hline Ada & 2 & 33,3 & 4 & 40 & 6 & 15,8 \\
\hline Tidak ada & 25 & 66,7 & 7 & 25 & 32 & 84,2 \\
\hline
\end{tabular}

Berdasarkan hasil penelitian di atas indikasi SC sebagian besar tidak berisiko infeksi dan penyembuhan luka baik sebesar 19 responden $79,2 \%$ ). Anemia sebagian besar tidak anemia dan penyembuhan luka baik yaitu $20(74,1 \%)$. Untuk riwayat DM sebagian besar responden tidak memiliki riwayat DM dan penyembuhan luka baik yaitu $25(66,7 \%)$.

Tabel 2.

Uji Hubungan Indkasi SC, Anemia Riwayat SC dengan Penyembuhan Luka SC

\begin{tabular}{|c|c|c|c|c|c|}
\hline \multirow{3}{*}{ Variabel } & \multicolumn{4}{|c|}{ Penyembuhan Luka } & \multirow{3}{*}{$P$-value } \\
\hline & \multicolumn{2}{|c|}{ Baik } & \multicolumn{2}{|c|}{ Tidak Baik } & \\
\hline & $\mathrm{N}$ & $\%$ & $\mathrm{~N}$ & $\%$ & \\
\hline \multicolumn{6}{|l|}{ Indikasi SC } \\
\hline Resiko infeksi & 4 & 57,1 & 3 & 42,9 & \multirow{3}{*}{0,353} \\
\hline Tidak resike infeksi & 19 & 79,2 & 5 & 20,8 & \\
\hline Riwayat SC & 4 & 51,7 & 3 & 42,9 & \\
\hline \multicolumn{6}{|l|}{ Anemia } \\
\hline Anemia & 2 & 25,9 & 0 & 0 & \multirow[t]{2}{*}{0,932} \\
\hline Tidak anemia & 20 & 74,1 & 11 & 47,8 & \\
\hline \multicolumn{6}{|l|}{ Riwayat DM } \\
\hline Ada & 2 & 33,3 & 4 & 40 & \multirow[t]{2}{*}{0,026} \\
\hline Tidak ada & 25 & 66,7 & 7 & 25 & \\
\hline
\end{tabular}

Berdasarkan tabel 2 di atas hasil uji statistik indikasi SC, anemia dengan penyembuhan luka post SC nilai $p$ value lebih dari 0,005 yang berarti tidak ada hubungan antara indikasi SC, anemia terhadap penyembuhan luka. Sedangkan untuk variabel riwayat DM dengan penyembuhan luka post SC $p$ value kurang 0,005 yang berarti ada hubungan terhadap penyembuhan luka

\section{PEMBAHASAN}

1. Indikasi SC dengan Penyembuhan Luka Post SC

Berdasarkan hasil uji statistik indikasi SC dengan penyembuhan luka post SC nilai $p$ value lebih dari 0,005 yang berarti tidak ada hubungan antara indikasi SC terhadap penyembuhan luka. Hal ini disebabkan karena dalam penelitian ini sebagian besar responden dengan indikasi SC tidak memiliki resiko infeksi. Berdasarkan hasil penelitian indikasi SC merupakan salah satu faktor penentu kecepatan kesembuhan luka post sectio caesaria karena dengan adanya infeksi yang terjadi sebelumnya menyebabkan luka yang ada akan lebih lama sembuhnya. Persalinan yang berisiko terhadap infeksi terhadap luka seperti partus lama, Ketuban Pecah Dini ${ }^{5}$

2. Anemia dengan Penyembuhan Luka Post SC

Berdasarkan hasil uji statistik anemia dengan penyembuhan luka post SC nilai $p$ value lebih dari 0,005 yang berarti tidak ada hubungan antara anemia terhadap penyembuhan luka. Hal ini bisa disebabkan karena dalam penelitian ini sebagian besar responden responden tidak anemia. Anemia merupakan suatu kondisi medis dimana jumlah sel darah merah atau hemoglobin kurang dari normal. Penurunan hemoglobin dalam darah (anemia) akan mengurangi tingkat oksigen arteri dalam kapiler dan menganggu perbaikan jaringan SC biasanya melibatkan peningkatan kehilangan darah jika dibandingkan dengan persalinan spontan per vaginam. Seberapa banyak kehilangan darah yang dapat membahayakan kondisi individu wanita tidak diketahui secara pasti, tetapi memastikan bahwa ibu tidak anemia baik sebelum maupun setelah pembedahan merupakan tindakan yang bijaksana karena anemia dapat menganggu penyembuhan luka ${ }^{6}$.

3. Riwayat DM dengan Penyembuhan Luka

Post SC

Penyembuhan luka post operasi section caesarea (SC) dimana terdapat hubungan yang signifikan antara penyakit $D M$ (Diabetes Mellitus) dengan penyembuhan luka, dengan nilai probabilitas $\mathrm{p}=0,012<$ 0,05 . Setelah dilakukan penelitian kepada 38 responden, 3 orang $(7,89 \%)$ mengalami infeksi dan dari ketiga orang tersebut semuanya menderita DM sehingga berpotensi terjadi infeksi pada luka operasinya. Diabetes menyebabkan peningkatan ikatan antara hemoglobin dan oksigen sehingga gagal untuk melepaskan oksigen ke jaringan. Salah satu tanda penyakit diabetes adalah kondisi hiperglikemia yang berlangsung terus menerus. Hiperglikemi menghambat leukosit melakukan fagositosis sehingga rentan terhadap infeksi. Jika mengalami luka akan sulit sembuh karena diabetes mempengaruhi kemampuan tubuh untuk menyembuhkan diri dan melawan infeksi. Maka dari itu apabila seseorang tersebut menderita penyakit DM dengan kadar gula yang sangat tinggi akan membuat proses 


\begin{abstract}
penyembuhan luka berjalan lambat ${ }^{7}$.Diabetes menyebabkan peningkatan ikatan antara hemoglobin dan oksigen sehingga gagal untuk melepaskan oksigen ke jaringan. Salah satu tanda penyakit diabetes adalah kondisi hiperglikemia yang berlangsung terus menerus. Hiperglikemi menghambat leukosit melakukan fagositosis sehingga rentan terhadap infeksi. Padapenderita DM membutuhkan waktu lebih lama dalam penyembuhan luka membutuhkan kesabaran ekstra dalam merawatnya, karena pada penderita DM luka kecil sekalipun akan sulit untuk disembuhkan ${ }^{8}$.
\end{abstract}

\section{KESIMPULAN DAN SARAN}

Faktor indikasi SC anemia tidak berhubungan dengan proses penyembuhan luka,sedangkan riwayat DM berhubungan dengan penyembuhan luka post SC. Bagi pelayanan kesehatan terutama di Rumah sakit riwayat DM harus ditanyakan dalam anamesa karena dapat mempengaruhi penyembuhan luka.

\section{DAFTAR PUSTAKA}

1. Sofian A. 2011. Jakarta: EGC; Sinopsis Obstetri. 195:220-3. p.
2. R DK. Laporan Nasional Riset Kesehatan Dasar (Riskesdas) tahun 2010. Jakarta: Badan Penelitian dan Pengembangan; 2010.

3. N M. Postpartum anemia II: Prevention And Treatment. . Annals Of Hematology. 2012;91(2):143-54.

4. Damayanti I. Faktor-Faktor Yang Berhubungan Dengan Penyembuhan Luka Post Sectio Caesarea Di RSUD Arifin Achmad Provinsi Riau Tahun 2013. Jurnal Kesehatan Komunitas. 2014;2(5):207-10.

5. NN RP. Hubungan Riwayat SC (Partus Kasep) Dengan Penyembuhan Luka Post Sectio Caesaria. 2014.

6. Proverawati. Anemia dan Anemia Dalam Kehamilan. Yogyakarta:: Nuha Medika; 2011.

7. Pramudiarja ANU. Penyebab Luka Penderita Diabetes Susah Sembuh: Artikel Detik Health; 2010.

8. Puspitasari HA. Faktor-faktor Yang Mempengaruhi Proses Penyembuhan Luka Post Operasi Sectio Caesarea (SC) RS PKU Muhammadiyah Gombong. SkripsiJurusan Keperawatan STIKes Muhammadiyah Gombong. 2011. 